Karstenia 48: 49-56, 2009

\title{
Field and moist chamber collections of Paraguay myxomycetes
}

\author{
ROLAND McHUGH
}

\begin{abstract}
McHUGH, R. 2009: Field and moist chamber collections of Paraguay myxomycetes. Karstenia 48: 49-56. Helsinki. ISBN 0453-3402.

During June-July 2008 the author visited Paraguay with the objective of collecting myxomycetes, and substrates from which they might be cultured. This resulted in a count of 73 species, bringing the total for the country to 90 species. A new species, Physarum minutum, is described.
\end{abstract}

Key words: Paraguay myxomycetes, myxomycete distribution, Arcyria corymbosa, Licea, Physarum minutum

Roland McHugh, Dublin Institute of Technology, Cathal Brugha Street, Dublin 1, Ireland; e-mail roland.mchugh@dit.ie

\section{Introduction}

In addition to accounts of the myxomycete floras of individual countries in South America, the entire continent has been considered by Farr (1976) and by Lado and Wrigley de Basanta (2008). Paraguay has a particularly low count, only 20 species having been recorded. It therefore appeared desirable to further investigate the country and during the summer of 2008 several localities in Paraguay were visited. Of the 73 species obtained in consequence of this, all but 3 were new to Paraguay.

\section{Methods}

Field collections were made by examining dead sticks, logs etc. and the organisms transported from the field by pinning them into a corklined box. A technique which had never been employed for the published records was the moist chamber culture of myxomycetes on substrates collected in the field. The most popular substrate is the bark of living trees: portions are removed and immediately sealed in envelopes. Subsequently they are placed cut side down on filter papers in Petri dishes. Having been soaked in distilled water for 24 hours, excess water is poured off and the surfaces periodically scanned with a stereoscope over the next few months, the material being kept damp. Myxomycetes fruit on the surface, frequently minute species which could hardly be detected in the field. Bark samples from various localities in Paraguay were treated in this manner, but unfortunately the trees providing the bark were in most cases not identified. In addition to bark, portions of dead cacti have proved useful for moist culture if treated in the same way. In situations of high humidity bark culture is often unproductive, but here lianas offer an interesting alternative (Wrigley de Basanta et al. 2008). Accordingly, both cactus and liana material was collected when appropriate.

\section{Collecting localities}

Paraguay is crudely divisible into the regions to the East and West of the river Paraguay. To the East lies a mixture of cultivated fields and wetlands with some humid forest. To the West is the Chaco, which becomes increasingly dry as one proceeds, eventually forming a mixture of savannah and thorn forest.

The following localities were sources of material for this study:

Aregua $\left(57^{\circ} 48^{\prime} \mathrm{W}, 57^{\circ} 48^{\prime} \mathrm{S}\right)$ is a town $30 \mathrm{~km} \mathrm{E}$ of Asuncíon. Bark samples were taken from three trees here on 6 July, for moist chamber culture. 
Asuncion Botanic Gardens (57³9’W, 254' S): parkland with scattered trees. Bark from a Tecoma impetiginosa was collected here on 14 July.

Cerro Cora National Park $\left(56^{\circ} 05^{\prime} \mathrm{W}, 22^{\circ} 45^{\prime} \mathrm{S}\right)$ is in the Department of Amambay, $40 \mathrm{~km}$ from Pedro Juan Caballero. Described by Clark (2006) as transitional between the Upper Parana Atlantic Forest and Cerrado Ecoregions, it has cacti growing among the trees. It was visited on 11 July but few myxomycete species were found in the field, probably because over one week's dry weather preceded the visit. However, tree bark was collected. A cactus sample in moist culture failed to produce any myxomycetes.

Filadelfia $\left(60^{\circ} 09^{\prime} \mathrm{W}, 22^{\circ} 30^{\prime} \mathrm{S}\right)$ is a town in the dry Chaco on the Transchaco Highway which runs from Asuncíon into Bolivia. The predominant vegetation is thorn forest with candelabra cacti. This is generally fenced off, but wide margins between the roads and fences are generally filled by a continuation of the vegetation, so that bark samples from both trees and cacti could be obtained. Two roads were investigated on 8 July: the Transchaco Highway West of Filadelfia and the road North towards Fortin Teniente Martinez. A succession of halts was made on each road for substrate collection. Owing to the general dryness, no myxomycetes were found in the field.

Moises Bertoni Scientific Monument $\left(54^{\circ} 42^{\prime} \mathrm{W}\right.$, $\left.25^{\circ} 45^{\prime} \mathrm{S}\right)$ is a protected area lying in the Department of Alto Parana adjacent to the river Parana, about $17 \mathrm{~km} \mathrm{~S}$ of Ciudad del Este. It was used for experimental forestry in the early $20^{\text {th }}$ century by the naturalist Moises Bertoni. Myxomycetes and tree bark samples were collected on 2 July from various trails which fan out from the Adminis-

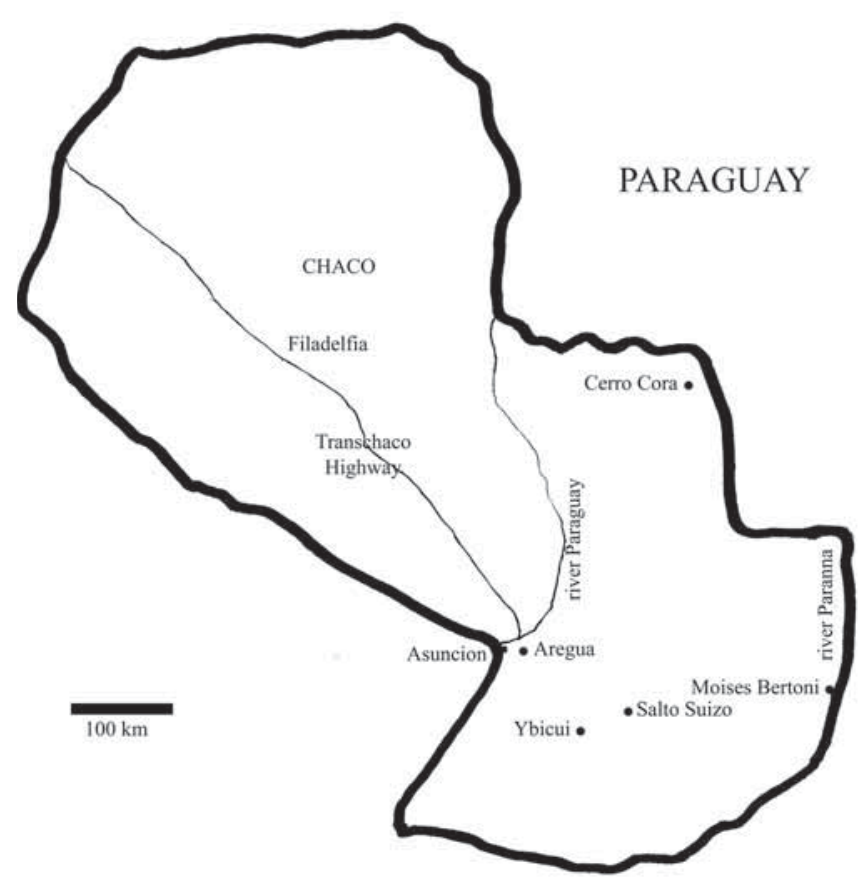

Fig. 1 Map of Paraguay. Bar $=100 \mathrm{~km}$. tration centre.

Salto Suizo ('Swiss Falls') lies in the Yvytyrusu Resource Management Reserve (56 $\left.18^{\circ} \mathrm{W}, 25^{\circ} 59^{\prime} \mathrm{S}\right)$, in the Department of Guaira, $25 \mathrm{~km} \mathrm{~N}$ of Villaricca. It is largely covered by semideciduous forest and is part of the Upper Parana Atlantic Forest Ecoregion. Collections of myxomycetes and tree bark were made near the base of the 'Swiss Falls' on 3 July.

Ybycui National Park (5706'W, $26^{\circ} 48^{\prime}$ 'S) was visited on 29 June. Situated in the Department of Paraguari, about $150 \mathrm{~km}$ SE of Asuncíon, it is a remnant of the Upper Parana Atlantic Forest. It includes numerous tree species although primary forest is restricted to inaccessible tracts. With its high humidity, the upper path from the visitor centre to the lookout at $600 \mathrm{~m}$ possesses many lianas but cacti were also found growing between the trees. Samples of tree bark, liana and cactus were collected here in addition to myxomycetes fruiting in the field. The lower path beside the river Mina to the 'Hidden Waterfall' (Salto Escondido) had no cacti but myxomycetes and tree bark samples were taken here.

\section{Results}

The following list of species provides for each taxon an index to the site, followed by the accession number in the author's herbarium. Nomenclature generally follows the system of Lado (2001). Colours are identified in accordance with the coding of Kornerup and Wanscher (1967). Sources are labelled with the following conventions:

AB1: Aregua bark culture from Salix sp. by Lake Yapacarai.

AB2-3: Bark cultures from unidentified trees between Aregua railway station and lake.

BB: Bark culture of Tecoma impetiginosa, Asuncíon Botanic Gardens.

CB1-4: Bark cultures from unidentified trees, Cerro Cora National Park, on bank of the river Aquidaban Nigui. CB5: Bark culture from unidentified tree near entrance to Cerro Cora National Park

CF: Cerro Cora National Park field collections.

FB1: Bark culture from Chorisia insignis by Transchaco Highway $13 \mathrm{~km}$ from Filadelfia.

FB2: Bark culture from unidentified tree by Transchaco Highway $26 \mathrm{~km}$ from Filadelfia.

FB3: Bark culture from unidentified 
tree by Transchaco Highway $30 \mathrm{~km}$ from Filadelfia.

FB4: Bark culture from unidentified tree by Transchaco Highway $34 \mathrm{~km}$ from Filadelfia.

FB5: Bark culture from unidentified tree by road $7 \mathrm{~km} \mathrm{~N}$ of Filadelfia.

FB6: Bark culture from unidentified tree by road $14 \mathrm{~km} \mathrm{~N}$ of Filadelfia.

FB7: Bark culture from unidentified tree by road $18 \mathrm{~km}$ N of Filadelfia.

FC1 Culture of cactus bark by Transchaco Highway $30 \mathrm{~km}$ from Filadelfia.

FC2: Culture of cactus bark by road $7 \mathrm{~km} \mathrm{~N}$ of Filadelfia.

FC3: Culture of cactus bark by road $8 \mathrm{~km} \mathrm{~N}$ of Filadelfia.

FC4: Culture of cactus bark by road $18 \mathrm{~km} \mathrm{~N}$ of Filadelfia .

FC5: Culture of cactus bark by road $20 \mathrm{~km} \mathrm{~N}$ of Filadelfia.

MB1: Bark culture from Artocarpus sp., Moises Bertoni Scientific Monument.

MB2: Bark culture from Ficus enormis, Moises Bertoni Monument.

MB3: Bark culture from Cupressus lusitanica, Moises Bertoni Monument.

MB4-9: Bark cultures from unidentified trees, Moises Bertoni Monument.

MF: Moises Bertoni Monument field collections. SB1-4: Bark cultures from Salto Suizo, Yvytyrusu Resource Management Reserve

SF: Salto Suizo field collections.

YB1-4: Ybycui National Park bark samples from upper path.

YB5-6: Ybycui bark samples from lower path.

YC: Dead cactus sample from upper path (?Epiphyllum).

YF: Ybycui field collections.

YL1-8: Dead liana samples from Ybycui upper path.

\section{Annotated list of species}

\section{ACRASIALES}

Pocheina rosea (Cienk.) Loeblich \& Tappan. YB2 1432

This organism is often included in treatments of corticolous myxomycetes. The culture, with a $\mathrm{pH}$ of 3.5, produced only Pocheina and no myxomycetes whatever.

\section{MYXOMYCETES}

\section{ECHINOSTELIALES}

Clastoderma debaryanum A. Blytt var. debaryanum MB5 1472, SB3 1570, YB3 1560

The stalk swelling was reduced or absent in 1560 .

Echinostelium arboreum H.W. Keller \& T.E. Brooks MB1 1420

E. colliculosum K.D. Whitney \& H.W. Keller FB1 1576, FB6 1429

E. minutum de Bary MB4 1546, MB9 1586, YB4 1604

E. paucifilum K.D. Whitney AB2 1516

Seldom recorded but known from Austria and North America.

\section{LICEALES}

Cribraria intricata Schrad. YF 1404

Decayed material on a log near the lookout point. C. violacea Rex MB3 1521, MB6 1482, SB4 1478, YB3 1565

Licea belmontiana Nann.-Bremek. SB3 1551, SB4 1477, FB2 1479, FB4 1544, FB6 1514, YB3 1534

L. biforis Morgan AB1 1436, AB3 1590, CB2 1503, FB6 1481, FC1 1540, MB1 1524, SB4 1509, YB1 1506

L. castanea G. Lister CB1 1471, YB3 1566

L. denudescens H.W. Keller \& T.E. Brooks CB3 1574

L. erecta K.S. Thind \& Dhillon YB1 1466, YB4, 1585

L. floriformis T.N. Lakh. \& R.K. Chopra MB2 1434, MB7 1587

L. kleistobolus Martin AB3 1615, YB6 1558

L. operculata (Wingate) G.W. Martin SB1 1439

L. pedicellata H.C. Gilbert (H.C. Gilbert) FB1 1598, FB5 1456, SB1 1424

L. perexigua T.E. Brooks \& H.W. Keller CB1 1502

L. pseudoconica T.E. Brooks \& H.W. Keller FB2 1427, YB4 1589

The spore in 1427 was only ca $5 \mu \mathrm{m}$ in diameter.

L. pygmaea (Meyl.) Ing FB4 1543

L. rugosa var. rugosa Nann.-Bremek. \& Y. Yamam. FB4 1498

L. scyphoides T.E. Brooks \& H.W. Keller CB2 1552, FB1 1580, FB6 1445, SB4 1449 
The spore in 1580 was small (only $8-9 \mu \mathrm{m}$ )

L. succulenticola Mosquera, Lado, Estrada-Torres \& Beltrán-Tej FC3 1513

Apparently confined to dead succulents, this species is probably quite common. Known from Europe and Ecuador.

L. sp. SB2 1553

Sporocarps (Fig. 2) scattered, sessile, 0.1-0.2 $\mathrm{mm}$ diameter, consisting of a roughly spherical mass of spores enclosed in a membranous peridium varying from medium brown to almost black in reflected light (5.D4-F3), and having a matt surface texture. This rests in a basal cup which is black and polished. The edge of the cup protrudes as a flange: this appears hyaline except for the extreme edge which is black. In transmitted light both the upper peridium and the cup are translucent light brown. Dehiscence is circumscissile. The spores are 9-10 $\mu \mathrm{m}$ diameter, pale violaceous brown (6.C2), minutely roughened and with a clear area occupying about one third of the surface. In a minority $(<10 \%)$ of cases thin ridges of black material appearing identical with that of the cup run across the spore mass, dividing it into several regions resembling the plates found, for example, in L. testudinacea. The edges of these regions do not present the string of knobs found in most plated Licea species. The closest affinity would appear to be with $L$. rufocuprea, particularly the material illustrated by Mitchell (2008); this however also displays knobs along the edge of the cup.

Lycogala conicum Pers. MF 1405

Fruiting on a log.

L. terrestre Fries. YF 1403

Fruiting on a log beside the river Mina.

\section{TRICHIALES}

Arcyria cinerea (Bull.) Pers. AB3 1603, BB 1579, CF 1416, MB8 1618, MB4 1526, MF 1408, SB3 1569, YL2 1517, YL3 1459, YL4 1538

1408 and 1416 were both found on sticks on the ground; 1603 consisted partly of the multidigitate form which has been recorded several times in South America (see for example Schnittler et al. (2002).

A. corymbosa M.L. Farr \& G.W. Martin SF 1414 A very rare species, reported from Argentina and Brazil, this was found as a white plasmodium beginning to fruit on a large mossy stick. Fruiting was completed in the collecting box (Fig. 3).
A. denudata (L.) Wettst. MF 1413

Two collections on logs.

A. insignis Kalchbr. \& Cooke MB4 1460

A. minuta Buchet MF 1412

On a large stick.

Calomyxa metallica (Berk.) Nieuwl. CB3 1596, CB5 1597, FB1 1582, FB2 1510, FB5 1454, FB6 1484, MB1 1525, MB2 1451, SB3 1440, SB4 1446, YB3 1474

Dianema depressum (Lister) Lister FC5 1461

Hemitrichia calyculata Speg. MF 1410

On stick on the ground. This species is already known from Paraguay.

H. minor G. Lister MB7 1602, SB2 1469

H. pardina Minakata MB1 1463, MB6 1483, MB7 1616, SB4 1475, YL5 1458

Apart from the last collection, all these $H$. pardina had a stalk several times the diameter of the sporotheca, which is unusual.

Perichaena chrysosperma (Curr.) Lister AB2 1499, BB 1530, CB1 1507, CB2 1559, CB4 1599, FC2 1490, MB1 1462, MB3 1453, MB4 1527, MB5 1512, MB6 1536, MB7 1588, MB8 1600, SB1 1508

P. corticalis (Batsch.) Rostaf. CB2 1504, FB2 1480, FB4 1542, SB1 1568, SB3 1468, YC 1549

P. depressa Lib. YL7 1612

P. dictyonema Rammeloo YC 1464

Known from Central Africa, Queensland, Puerto Rica and Ecuador.

P. vermicularis (Schwein.) Rostaf. YC 1465

Trichia munda (Lister) Meyl. YB3 1444

\section{PHYSARALES}

Badhamia affinis var. armillata (Nann.-Bremek.) Y. Yamam. YL8 1564

There were two sessile sporocarps in this collection and all the others had abnormally long stalks, giving the macroscopic view the aspect of a Physarum. However, the large spores with a line running across them were normal for this variety.

— Figs. 2: Licea sp. RM1553. Bar $=100 \mu \mathrm{m} .-3:$ Arcyria corymbosa RM1414, Bar $=500 \mu \mathrm{m} .-4:$ Physarum minutum RM 1522. Bar $=100 \mu \mathrm{m} .-5:$ Physarum sp. $\mathrm{RM}$ 1417. Bar $=100 \mu \mathrm{m} .-6:$ Physarum minutum $\mathrm{RM}$ 1522, Nomarski DIC. Bar $=30 \mu \mathrm{m} .-7:$ Physarum $\mathrm{sp}$. RM1417, Nomarski DIC. Bar $=30 \mu \mathrm{m}$. 


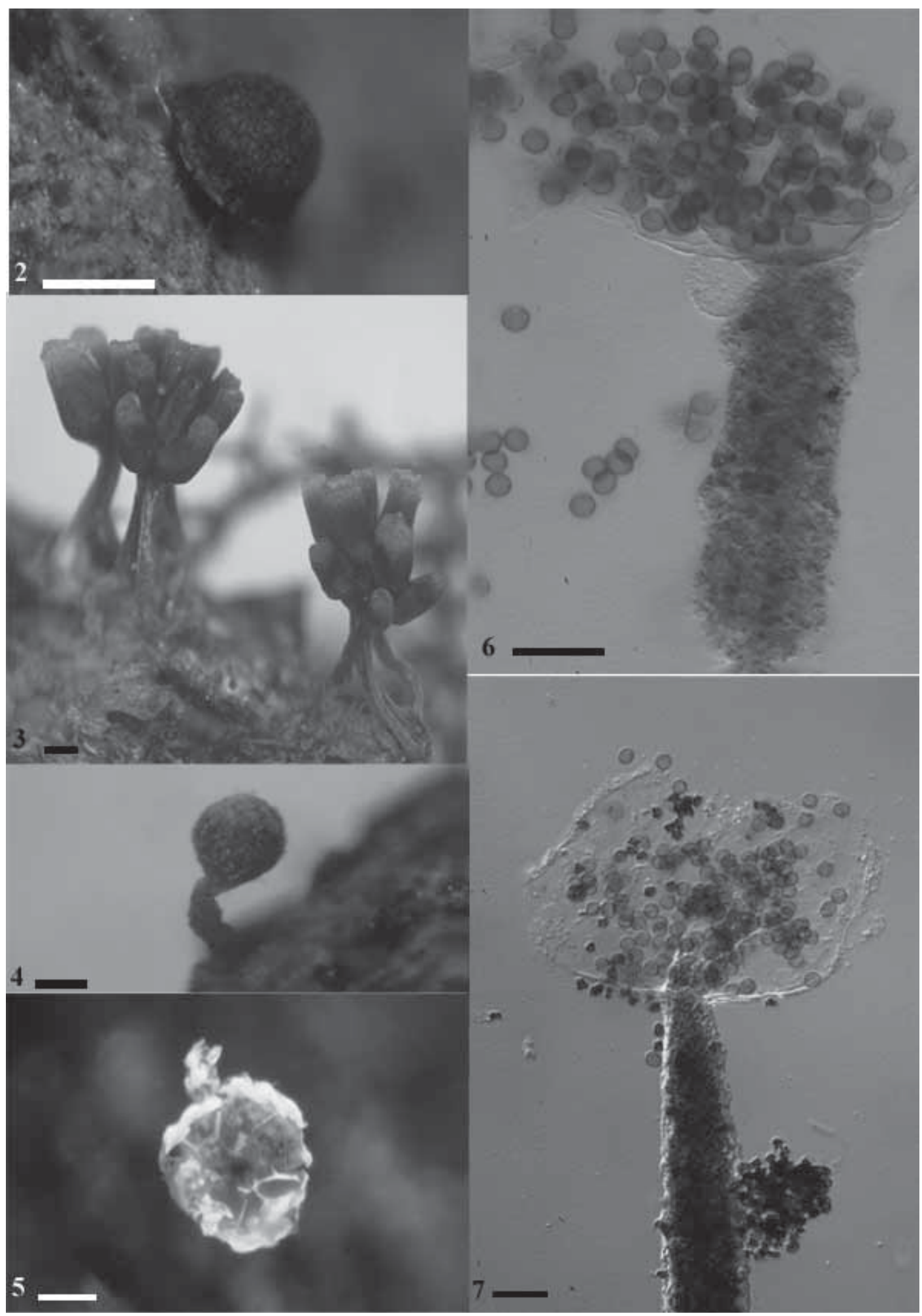


B. melanospora Speg. FB3 1595, FC3 1431

Probably the commonest myxomycete occurring on dead cactus material.

Badhamiopsis ainoae (Yamash.) T.E. Brooks \& H.W. Keller BB 1531, FB5 1457

Diderma chondrioderma (de Bary \& Rostaf.) G. Lister FB6 1561, MB1 1591, MB3 1532

D. effusum (Schwein.) Morgan BB 1578, FB5

1491, MB4 1547, SB2 1554, SB3 1486, SB4 1562

Didymium clavus (Alb. \& Schwein.) Rabenh. MB1 1523

D. iridis (Ditmar) Fr. YC 1423

D. bahiense var. microsporum Hochg., Gottsb. \& Nann.-Bremek. FC2 1572

D. melanospermum (Pers.) T. Macbr. MF 1411

On dead herbaceous stem.

D. ochroideum G. Lister FC2 1435

D. squamulosum (Alb. \& Schwein.) Fr. MF 1409

An extensive fruiting on sticks and leaves. The species has been already recorded from Paraguay.

Physarum album (Bull.) Chevall. FC5 1497, MB8 1593, SF 1415

1415 was found on bark peeling from sticks.

P. braunianum de Bary FB5 1455

P. compressum Alb. \& Schwein. CF 1418, FC2

1520, FC4 1556, FC5 1548

1418 consisted of three collections on moribund palm leaves.

P. crateriforme Petch AB1 1495, FB2 1426, FB5

1492, MB2 1450 SB4 1448

P. decipiens M.A. Curtis MB4 1528, YL1 1493, YL6 1537

The spore in 1537 measured only $8-10 \mu \mathrm{m}$ in diameter.

P. didermoides (Pers.) Rostaf. FB4 1541, FC1 1567, YL7 1601

P. leucophaeum Fr. BB 1422, CB3 1575, MB3

1433, MB5 1443, SB3 1441, YL1 1494

\section{P. minutum McHugh nov. sp. - Figs. 4, 6}

Sporangia dispersa, stipitata, sine hypothallo, argenteo-nitentia, $0.1-0.2 \mathrm{~mm}$ in diam. Stipes erectus, $0.1-0.2$ (raro ad 0.7) mm. longus, brunneus, materia granulata instructus, apicem versus attenuatus. Peridium decoloratua sed basi pallido-ochraceum, interdum calcis albi incrustatum ad parti superiorem. Columella nulla. Capillitium exiguum, ex filamentis gracilibus, nodi albi rotundati ad fusiforme, Dehiscentia ir- regularis. Sporae in cumulo fuscae, luce transmisso violaceo-griseae, paene laeves, 8-10 $\mu \mathrm{m}$. in diameter.

Sporocarps scattered, stipitate, globose, shining silvery, without hypothallus, $0.1-0.2 \mathrm{~mm}$ in diameter. Stalk erect, $0.1-0.2$ (rarely to 0.7 ) $\mathrm{mm}$ tall, brown, containing granular material, tapering at apex. Peridium hyaline but yellow at base, sometimes with a white limy incrustation on the upper part. Columella absent. Capillitium sparse, of thin colourless threads, nodes round to fusiform, white. Dehiscence irregular. Spores in mass brown, by transmitted light violaceous grey (15.B2), almost smooth, $8-10 \mu \mathrm{m}$ in diameter.

- Type: Paraguay: Moises Bertoni Scientific Monument, on bark of Cupressus lusitanica in moist chamber culture. R. McHugh 1522 (Type preserved in the herbarium of the Irish National Botanic Gardens, Glasnevin, Dublin).

The name reflects the small stature of this Physarum, which was initially mistaken for a Licea.

CB5 1425, MB3, 1522

P. nucleatum Rex MF 1407

P. pusillum (Berk. \& M.A. Curtis) FB6 1487, YL5 1488

P. robustum (Lister) Nann.-Bremek. CB2 1467, FB4 1437

P. viride (Bull.) Pers. SB4 1555, YB5 1529

Already known from Paraguay

P. viride var. incanum Lister AB3 1573

P. sp. CF 1417

Sporocarps scattered, stipitate, globose, thickly coated with white lime, ca. $0.2 \mathrm{~mm}$ diameter. Total height ca, $1 \mathrm{~mm}$. Hypothallus not evident. Stalk erect, tapering upwards, black in reflected light. In transmitted light black at base, becoming translucent brown above, filled with refuse matter. Peridium double, the outer layer limy and closely attached to the thin iridescent inner layer, which is finely warted. Capillitium rigid, limy, white, radiating from the conical brown columella at the base of the sporotheca, sometimes badhamioid. Lime nodes not seen. Spores in mass brown, in transmitted light pale violaceous grey (6.C2), minutely roughened, $10-12 \mu \mathrm{m}$ in diameter.

The sporocarps (Figs. 5, 7) were found amongst Physarum compressum 1418 on moribund palm leaves. An affinity with P. xylophilum is possible, but this species has abundant capillitium and 
lime nodes.

Trabrooksia applanata H.W. Keller MB3 1545, SB3 1442

\section{STEMONITALES}

Colloderma oculatum (C. Lippert) G. Lister AB2 1500, CB2 1505, FC2 1563, MB8 1594, SB2 1585, SB3 1592, SB4 1476

Comatricha elegans (Racib.) G. Lister FB1 1577 C. nigra (Pers. ex. J.F. Gmel.) J. Schröt. YL4 1539

C. pulchella (C. Bab.) Rostaf. CB1 1533, YL1 1518, YL4 1489

C. aff. suksdorfii Ellis \& Everh. YB3 1511

These sporocarps were abnormally small, reaching only ca. $1 \mathrm{~mm}$ in height, and there were no peridial flakes on the surface.

Enerthenema melanospermum T. Macbr. \& G.W. Martin FB1 1581

Macbrideola martinii (Alexop. \& Beneke) Alexop. CB1 1470, CB4 1584, MB1 1438, MB3 1452, MB6 1515, MB7 1571, SB4 1447, YB3 1535

M. scintillans var. verrucosa (Nann.-Bremek. \& Y. Yamam.) Y. Yamam. CB4 1583, MB1 1496

A tropical species known from Queensland, Japan, Panama and Mexico.

Paradiacheopsis rigida (Brândză) Nann.Bremek. AB2 1501, FB2 1428, FB4 1419, FB5 1421, FB6 1430

Stemonitis mussoriensis var. emotoi G.W. Martin, K.S. Thind \& Sohi YL2 1519

\section{Discussion}

In this study a total of 160 Petri dishes were prepared, of which 130 showed some myxomycete activity (not necessarily sporocarps). Restricting the figures to tree bark cultures, 111 out of 133 were successful.

Grouping field collections and moist cultures together, and ignoring 'Licea sp.' and 'Physarum sp.', 73 species (plus a variety) were obtained, with the orders Echinosteliales, Liceales, Trichiales, Physarales and Stemonitales producing respectively 5, 19, 16, 23 and 10 species. The low count of Stemonitales resembles that in collections from coastal Ecuador (McHugh 2005) of 2, 9, 10, 26 and 6 respectively, and Costa Rica
(Schnittler \& Stephenson 2000) of 2, 6, 7, 14 and 5.

The commonest species in moist culture were Perichaena chrysosperma (14 cultures), Calomyxa metallica (11) and Arcyria cinerea (10). In the Ecuador study the commonest species were Arcyria cinerea and Physarum oblatum (6 each) and Calomyxa metallica, Licea pedicellata, Physarum leucophaeum and Physarum oblatum (5 each). In the present study P. oblatum was not found and the counts for $L$. pedicellata and $P$. leucophaeum were 3 and 6 respectively.

The culture of liana material was confined to material from Ybycui National Park. Results were scanty, but Arcyria cinerea appeared three times and is one of the three commonest liana species according to the study by Wrigley de Basanta et al. (2008). The principal species of interest from Ybycui liana cultures were Badhamia affinis var. armillata and Stemonitis musooriensis var. emotoi.

Combining tree bark cultures from Moises Bertoni Monument, Salto Suizo and Ybycui (which all appear to share some attributes) $82 \%$ of dishes showed some myxomycete activity, compared with $100 \%$ for the Chaco. This accords with the general principle that cultures from regions of low rainfall give better results (see for example Schnittler \& Stephenson 2000). Average rainfall in the Chaco is $500-1000 \mathrm{~mm}$ per year compared with $1270 \mathrm{~mm}$ in the East of Paraguay. A number of prominent species from Eastern cultures were lacking from the Chaco ones, notably Arcyria cinerea, Colloderma oculatum, Hemitrichia pardina, Macbrideola martinii and Physarum leucophaeum. Cacti were far more abundant in the Chaco than elsewhere, and cactus cultures produced massive fruitings of several characteristic species, Badhamia melanospora, Licea succulenticola, Physarum compressum and $P$. didermoides. By contrast, cactus from Ybycui showed none of those four, but did produce Perichaena dictyonema and $P$. vermicularis, not recorded from the Chaco. All this accords with the division of the country into East and West already described.

Acknowledgements: I should like to thank Tony Hutchinson for assistance with photography. 


\section{References}

Clark, P.T. 2006: Guide to Paraguay's National Parks and other Protected Wild Areas. Obtainable fron the author (petertomclark@hotmail.com)

Farr, M.L. 1976: Flora Neotropica Monograph no 16. Myxomycetes. - New York Botanical Garden.

Lado, C. 2001: Nomenmyx. A nomenclatural taxabase of myxomycetes. - Cuadernos de Trabajo de Flora Micológica Ibérica 16: 1-221.

Lado, C. \& Wrigley de Basanta, D. 2008: A review of neotropical myxomycetes (1828-2008). - Anales Jard. Bot. Madrid 65: 211-254.

Kornerup, A. \& Wanscher, J.H. 1967: Methuen handbook of colour. $2^{\text {nd }}$ ed. - Methuen, London

McHugh, R. 2005: Moist chamber culture and field col- lections of Myxomycetes from Ecuador. - Mycotaxon 92: 107-118.

Mitchell, D.W. 2008: 'Myxomycetes'. DVD of keys and inventory of all world species. - Private publication by the author, annually updated.

Schnittler, M., Lado, C. \& Stephenson, S.L. 2002: Rapid biodiversity assessment of a tropical myxomycete assemblage - Maquipucuna Cloud Forest Reserve, Ecuador. - Fungal Diversity 9: 135-167.

Schnittler, M. \& Stephenson, S.L. (2000) Myxomycete diversity in four different forest types in Costa Rica. Mycologia 92: 626-637.

Wrigley de Basanta, D., Stephenson, S.L., Lado, C., Estrada-Torres, A. \& Nieves-Rivera, A.M. 2008: Lianas as a microhabitat for myxomycetes in tropical forests. - Fungal Diversity 28: 109-125. 